УДК 338

doi: 10.15330/apred.2.17.204-211

\title{
ЧАЙОВІ В РЕСТОРАННОМУ БІЗНЕСІ
}

Румянцева І.Б.

Прикарпатський національний університет

ім. В. Стефаника, кафедра готельно-ресторанної та курортної справи, вул. Галицька 201 б, м. Івано-Франківськ, 76000 , Україна, тел.: 0669779642, e-mail: rumjantseva@ukr.net, ORCID: 0000-0002-9940-3648

Анотація. Стаття присвячена дослідженню актуальності надання відмінного сервісу в закладах харчування, розвитку культури чайових та безготівкових чайових, тенденцій, що стосуються ресторанного бізнесу. Виявлено зниження відвідуваності закладів ресторанного господарства в період пандемії. Визначено основні причини такої тенденції. Охарактеризовано новації, що стосуються ресторанної справи.

Діяльність успішного закладу ресторанного бізнесу відображається в його діях. Такі заклади завжди на кілька кроків вперед серед своїх конкурентів. Вони аналізують не тільки сьогодення, а й майбутнє свого закладу, тому цікавляться новаціями та прийдешніми трендами, які будуть сприяти розвитку закладу ресторанного бізнесу та зможуть зробити його лідером своєї галузі.

В період пандемії ресторанний бізнес зазнав суттєвих втрат через певні карантинні обмеження. Для подальшого свого існування заклади харчування повинні були перейти на інший рівень надання послуг харчування. Такий рівень повинен був забезпечувати в першу чергу безпечність для своїх відвідувачів. Гості закладів харчування в період карантину стали бути досить прискіпливі у своєму виборі, важливим аспектом залишилася безпечність в наданні послуг харчування. Те саме і стосувалося залишання чайових для обслуговуючого персоналу.

У статті проаналізовано стан ресторанного бізнесу в період пандемії, визначено основні проблеми зменшення відвідуваності гостей в закладах харчування та запропонувано способи покращення ситуації на ринку ресторанних послуг в умовах карантину.

При вирішенні поставлених завдань нами використано ряд методів дослідження: методи статистичного аналізу - для оцінки стану ресторанного бізнесу в період пандемії, а також методи аналізу та синтезу, порівняльних характеристик щодо проблем відвідуваності в закладах харчування.

Перспективами подальшої наукової новизни є аналіз сучасних тенденцій розвитку науки у сфері ресторанного бізнесу, новинок у харчуванні та сфері послуг, впровадження новацій в обслуговуванні відвідувачів.

3'ясовано, що безпечна робота персоналу з впровадженням безконтактної оплати за послуги харчування стануть ефективним інструментом для збільшення відвідуваності в ресторанному бізнесі. Запропоновано розрахунок 3 відвідувачами в закладах харчування перевести на безконтактний та безпечний.

Ключові слова: ресторанний бізнес, якість послуги, харчування, чайові, електронні чайові, відвідувач.

\section{TIPS IN THE RESTAURANT BUSINESS}

Rumiantseva I.B.

Vasyl Stefanyk Precarpathian National University, the Department of hotel-restaurant and resort business, Halytska str, 201B, Ivano-Frankivsk, 


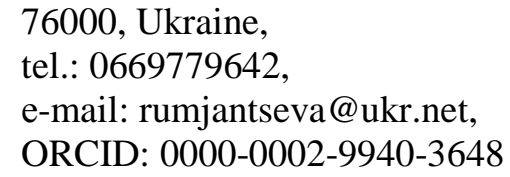

\begin{abstract}
The article is devoted to the study of the relevance of providing excellent service in catering establishments, the development of the culture of tips and non-cash tips, trends related to the restaurant business. There was a decrease in attendance at restaurants during the pandemic. The main reasons for this trend are identified. Innovations related to the restaurant business are described.

The activities of a successful restaurant business are reflected in its actions. Such establishments are always a few steps ahead of their competitors. They analyze not only the present but also the future of their establishment, so they are interested in innovations and future trends that will contribute to the development of the restaurant business and will be able to make it a leader in their industry.

During the pandemic, the restaurant business suffered significant losses due to certain quarantine restrictions. For their continued existence, catering establishments had to move to another level of catering services. This level was to provide security for its visitors in the first place. Guests of food establishments during the quarantine period began to be quite meticulous in their choice, an important aspect remained safety in the provision of food services. The same applied to leaving tips for service personnel.

The aim of the article is to analyze the state of the restaurant business during the pandemic, to identify the main problems of reducing the attendance of guests in restaurants and to suggest ways to improve the situation in the market of restaurant services in quarantine.

In solving the tasks we used a number of research methods: methods of statistical analysis - to assess the state of the restaurant business during the pandemic, as well as methods of analysis and synthesis, comparative characteristics of the problems of attendance in catering establishments.

Prospects for further scientific novelty are the analysis of current trends in science in the restaurant business, innovations in food and services, the introduction of innovations in customer service.

It has been found that the safe work of staff with the introduction of contactless payment for food services will be an effective tool to increase attendance in the restaurant business. It is proposed to transfer the settlement with visitors in food establishments to contactless and safe.
\end{abstract}

Key words: restaurant business, quality of service, food, tips, electronic tips, visitor.

Вступ. Сучасний ресторанний бізнес - це сфера надання якісних послуг харчування для відвідувачів. Це атмосфера закладу, куди хочуть повертатися відвідувачі.

Ресторан у розумінні сучасного відвідувача давно не пов'язаний виключно із потребою в їжі. Відвідувачів цікавить якість, цінова політика, рівень обслуговування, цікаві акції, індивідуальні особливості закладу. Уявити успішний ресторан, який не використовує сучасні технології, досить складно, особливо це відчутно стало в період пандемії.

За статистикою, більшість ресторанних гостей не проти давати чайові після того, як побували в улюбленому закладі з високим сервісом обслуговування та смачною їжею. У різних країнах світу сформувалася зовсім різна культура подяки за обслуговування своїх гостей. Офіціант у США може бігти за відвідувачем i обурюватись, що йому дали мало чайових, тоді як у Японії залишену на столі монетку працівники закладу харчування поспішають повернути як забуту.

Вважається, що чайові з'явилися у Британії у XVI столітті. Саме тоді в англійців зародилася традиція чаювання, і якщо гості залишалися ночувати в хаті господаря, то залишали гроші його слугам, це було подякою за відмінний сервіс.

Культура чайових у країнах західних помітно відрізняється від прийнятої на Сході. В одних країнах 10\% від суми слугуватиме подякою і це буде середня норма, десь такий відсоток чайових є доречним, тільки якщо ви незадоволені сервісом, а десь 
із вас не візьмуть і цього - і навіть вважатимуть образою для закладу. До прикладу у Британії вважається ввічливим дати 10\% чайових, якщо ви залишилися задоволені обслуговуванням, хоча у Британії, наприклад, не прийнято залишати їх у пабах. В Україні така традиція, як залишати чайові все більше набуває популярності серед відвідувачів.

Постановка завдання полягає в обгрунтуванні та глибшому вивченні питань, що стосуються трендів у ресторанному бізнесі, а саме: в українських закладах харчування 3'являється все більше нових форматів закладів, новинок, у тренді, користуватимуться попитом високотехнологічні способи приготування, при яких контакт кухаря з їжею зведений до мінімуму, привертатимуть увагу та симпатії споживачів також безконтактні операції, handsfree i навіть приготовлені страви роботами, без участі людини, i переведення закладів харчування на залишання чайових безпечним способом, стануть модними електронні чайові. Ключовими моментами роботи залишаються: якість, безпека, професіоналізм. Це викликано, насамперед, зростаючою потребою людей у харчуванні та проведенні дозвілля найперше безпечно та якісно.

Питанням дослідження, що стосуються якісного обслуговування та залишання чайових в закладах ресторанного бізнесу присвячено не так і багато праць. Зокрема, окремі аспекти діяльності ресторанного бізнесу висвітлено у працях: В.В. Архіпов [1], М.П. Мальська [2], В. П. Самодай [3] та інші. Грунтовні дослідження науковців щодо якісного ресторанного сервісу та залишання чайових відсутні. Недостатня кількість наукових праць 3 досліджуваного питання зумовлена швидкими змінами та трендами в сфері послуг. 3 огляду на це обрана тема $є$ актуальною та вимагає подальших досліджень.

Метою дослідження було виявлення змін розвитку ресторанного бізнесу в Україні в період пандемії. Закладам харчування необхідно постійно оновлювати перелік своїх послуг, обираючі такі, які найбільше будуть відповідати вимогам сучасних відвідувачів.

У статті було застосовано методи статистичного аналізу, аналізу та синтезу, порівняльних характеристик, що стосувалися виявлення сучасних тенденцій розвитку ресторанного бізнесу в період пандемії.

Результати. Сучасний ресторан, який надає послуги харчування на високому рівні в першу чергу цінує своїх гостей. Саме гості закладу сприяють розвитку їхньому бізнесу. Відвідувачі закладу харчування найкраще можуть дати реальний відгук про якісне обслуговування, а це в свою чергу робить заклад харчування конкурентоспроможним серед інших, створюється репутація ресторану. Повага до уваги відвідувача звичайно ж $є$ невід'ємним атрибутом будь-якого закладу харчування.

Очевидно, ефективність діяльності підприємств ресторанної індустрії цілком залежала від конкретного сегмента відвідувачів закладів харчування, рівня конкурентоспроможності певних ресторанів на ринку ресторанного бізнесу [3, с. 25].

В основу контролю якості продукції підприємств різних видів власності закладений принцип економічної залежності працівників від якості продукції, що випускається, тобто принцип економічної зацікавленості працівників у випуску продукції високої якості [1, с. 341].

Успіх закладу харчування залежить від якісної роботи всіх працівників закладу харчування. При високому сервісі, відвідувач закладу обов'язково залишить чайові.

Раніше чайові були вкрай небажаними - їх вважали буржуазним пережитком $\mathrm{i}$ спробою принизити робітничий клас. Однак вони існували завжди - наприклад, як спосіб зав'язати добрі стосунки з продавцем у епоху продуктового дефіциту. 
Сьогодні вважається чемним залишити 10\% від рахунку офіціанту, якщо ви залишилися задоволені сервісом. Проте, якщо чайових не залишати, навряд чи хтось вважатиме, що ви пішли незадоволеними.

У США на чай прийнято давати завжди, але розмір чайових варіюється в залежності від конкретного штату, місця (ресторан, бар, закусочна, доставка і т.д.) та задоволеності сервісом. У середньому розмір чайових - від 10 до $20 \%$.

Як і в більшості азіатських країн, у Китаї культура чайових не прижилася. Десятиліттями чайові були заборонені та вважалися хабарем. Досі дякувати за сервіс там не прийнято. У ресторанах, які відвідують місцеві жителі, офіціанти не одержують "на чай". Винятки - ресторани для туристів або готелі, які приймають іноземців - у такому разі чайові потрібно залишати лише носіям багажу. Ще в Китаї можна залишати чайові гідам та водіям туристичних автобусів.

Непроста система етикету Японії охоплює зокрема чайові. Вони соціально прийнятні в особливих випадках - таких, як весілля чи похорон. У більш скромній обстановці вони можуть змусити одержувача відчути себе приниженим.

Філософія японського етикету у тому, що хороший сервіс і так стоїть у японців на першому місці. Навіть на заходах, де чекають чайових, вони за протоколом подаються у спеціальних конвертах на знак подяки та поваги.

Працівників сфери обслуговування, які й так зазвичай ввічливі та кмітливі, тренують чемно відмовлятися від чайових.

У Швейцарії прийнято округляти рахунки, однак у цій країні одна 3 найвищих мінімальних зарплат у світі.

Наприклад, офіціант отримує понад чотири тисячі доларів на місяць. Тож вони не настільки залежні від чайових.

У багатьох ресторанах в Індії чайові включаються, тому можна не залишати їх спеціально. Проте з етикету варто залишити 15-20\%.

При цьому часто можна побачити ресторани, вивіски на яких повідомляють, що чайові давати не треба.

У сучасному світі звичайною практикою є чайові. Одним словом, чайові - це реакція на якість сервісу. Якщо їх залишають, значить, сервіс непоганий або навіть відмінний [7].

В Україні більшість (близько 95 \%) відвідувачів ресторанів справді готові давати чайові та дають їх. Тільки на відміну від Європи, у нас не завжди дотримуються традиції давати чайові у розмірі $10 \%$ від рахунку, найчастіше суму просто заокруглюють. Тобто якщо у рахунку 75 гривень, дають 80 і не беруть решти. Якщо сума чека досить велика (300-500 гривень), чайові можуть становити 50-80 гривень. Середня сума чайових у ресторані - 10-20 гривень. Не дають чайових у випадку, якщо гість залишився незадоволеним рестораном, якщо він не хоче псувати собі настрій i скандалити, це хороший спосіб коректно показати ресторану своє незадоволення.

Деякі ресторани в Україні включають чайові до рахунку. Насамперед це порушення законодавства, тому що гостю виставляють рахунок за послугу, яку він не замовляв. I потім це некоректно. Хороше обслуговування - обов'язок ресторану, і відвідувач не повинен платити окремо за нього. Може, але не винен. Сдиний виняток коли гість замовляє банкет чи фуршет. У такому разі під час замовлення обумовлюються обов'язкові чайові у розмірі 5-10 \% від загальної суми.

Гостинність - це комплексна послуга, що характеризується споживчими властивостями і зумовлює необхідність створення позитивного іміджу підприємства [2, c.57]. 
Включати чайові до рахунку - погана політика для ресторану. У такому разі чайові не стимулюють персонал працювати краще. Їх забирає ресторан, розподіляє «по сітці», і офіціант, який добре обслужив, зовсім не обов'язково отримає винагороду.

Оптимальний варіант - коли в чеку є фраза на кшталт: «чайові вітаються, але залишаються на розсуд гостя».

Заклади ресторанного бізнесу мають щоденно покращувати роботу своїх закладів i тоді не прийдеться включати чайові до рахунку гостя. Задоволений гість завжди віддячить за професіоналізм заклад в якому побував. В Україні традиційний розмір подяки - 10 \%. В тому випадку, якщо обслуговування на пристойному рівні.

В сучасних умовах відвідувачі закладу харчування віддячують персонал закладу за відмінний сервіс. Якщо раніше рахувалося, що чайові дають переважно офіціантові, то тепер все змінилося. Широкої популярності набувають чайові серед барменів та барист в яких першим завданням стоїть не обслуговування, а відмінно приготувати напій.

Чайові - традиційна форма винагороди за високу якість обслуговування, смачні страви та за фактом оцінка закладу. Ми не говоритимемо про те, правильно чи ні давати чайові[4]. Тим більше, що, за статистикою, 20\% відвідувачів взагалі не залишають на чай принципово. $Є$ декілька систем розподілу чайових серед персоналу.

В одному випадку чайові залишає собі офіціант, в іншому - зібрана за зміну сума поділяється на всіх офіціантів. $Є$ ресторани, де чайовими розпоряджається менеджер залу, вирішує кому і скільки, в деяких випадках під роздачу потрапляє шеф-кухар, бармен і молодший технічний персонал. Кожна 3 цих схем є ефективно по-своєму. Однозначної відповіді немає і в кожному випадку вона своя. По суті, рішення ухвалюється співробітниками спільно. Найчастіше вибір залежить від цілого ряду факторів. Так, наприклад, якщо мова про винагороду, отриману за обслуговування банкету, то сума може ділитися таким чином: 40\% - кухарям, 50\% - офіціантам, а 10\% технічному персоналу.

У результаті, яка б система чайових не застосовувалася у закладі, головне завдання закладу полягає в наступному, щоб ці чайові відвідувачі хотіли залишати.

Найчастіше чайові залишають працівникам у сфері обслуговування (рис. 1).

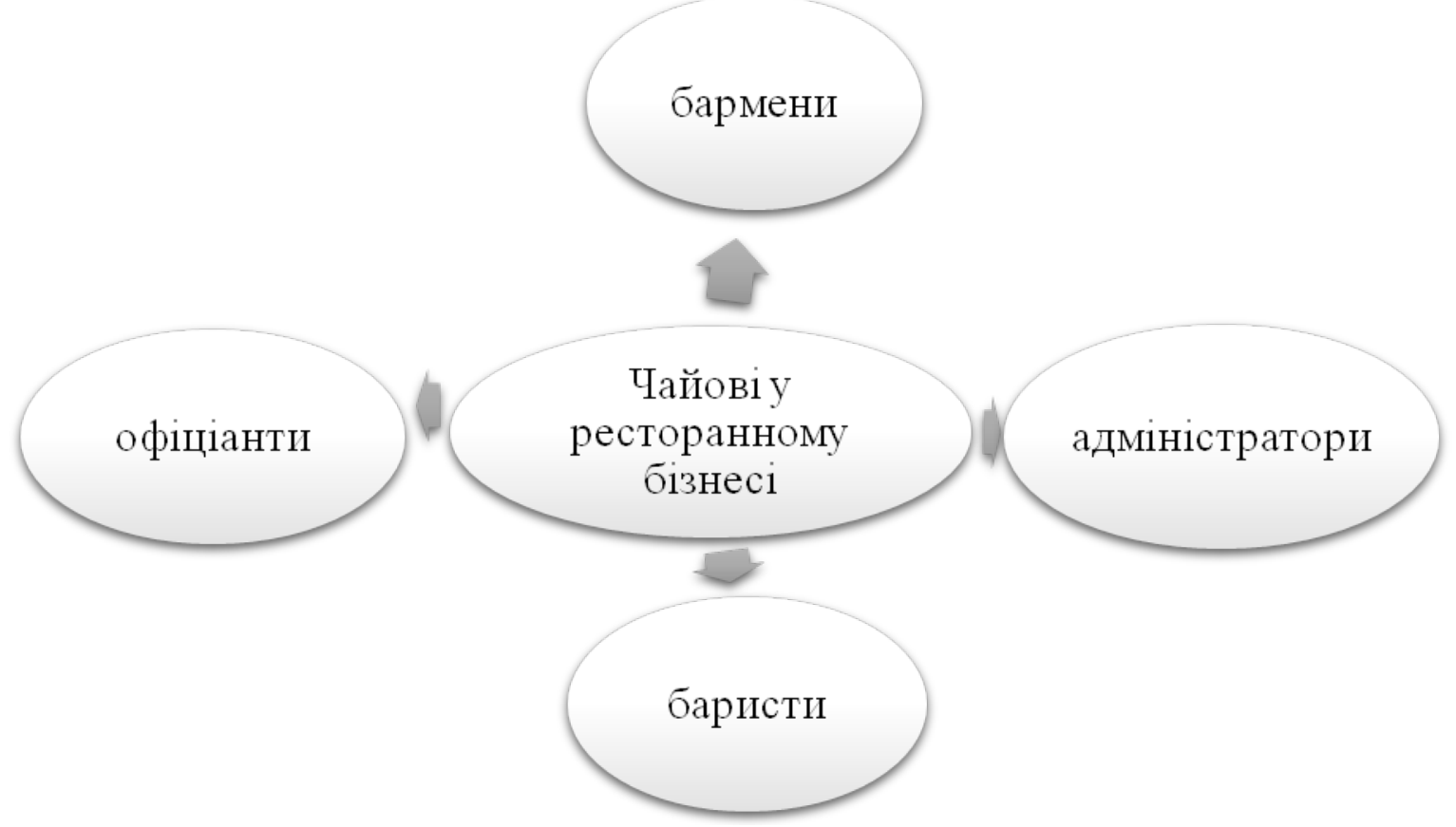

Puc. 1. Чайові у ресторанному бізнесі (розробка автора)

Fig. 1. Tips in the restaurant business (author's development) 
Ресторан у сучасному розумінні давно не пов'язаний виключно із потребою в їжі. Відвідувачів цікавить якість, цінова політика, рівень обслуговування, цікаві акції, індивідуальні особливості закладу. Уявити успішний ресторан, який не використовує сучасні технології, досить складно. Одним безкоштовним Wi-Fi нікого вже не здивуєш [8].

В період пандемії все більшої популярності набрала доставка їжі з ресторану. Послуга доставки та їжі на виніс надається майже в кожному закладі 3 гарною репутацією, а в смартфоні будь-якої сучасної людини можна знайти одну 3 найпопулярніших додатків доставки їжі.

Формати закладів, які раніше, в принципі, не працювали з доставкою (бари, паби, кав'ярні, заклади 3 караоке, кальянні), також боряться за гостей: багато хто пропонує акції та знижки за самовивіз страв і напоїв [5]. 3 огляду на це сьогодні для збереження бізнесу на перший план виносяться питання здійснення трансформацій у діяльності підприємств ресторанного бізнесу та розроблення інноваційних рішень [6]. Тому в період пандемії в закладах харчування почали впроваджувати електронні чайові.

Електронні чайові - один із помітних сучасних трендів ресторанного бізнесу. Активно почали вводити електронні чайові ще до початку пандемії.

Як показала практика, цей сервіс зручний: зрозумілий інтерфейс, все функціонує чітко та швидко. Позитивним моментом є те, що можна оцінити роботу офіціанта: система - аналогічна до тієї, що існує в інших додатках, п'ять зірочок. Плюс гості мають можливість залишити відгук про роботу ресторану, а платформа дозволяє ці відгуки відстежувати, аналізувати їх та навіть складати рейтинги.

Інформація про суму чайових, отриманих офіціантом, не $є$ конфіденційною, тому можна дізнатися суму чайових та оцінки, які співробітник отримав від гостей.

Власники кафе та ресторанів отримали можливість переналаштувати термінали оплати так, щоб офіціанти могли отримувати винагороди від клієнтів у безготівковій формі.

Процес отримання персоналом закладу харчування електронних чайових подано на рис. 2.

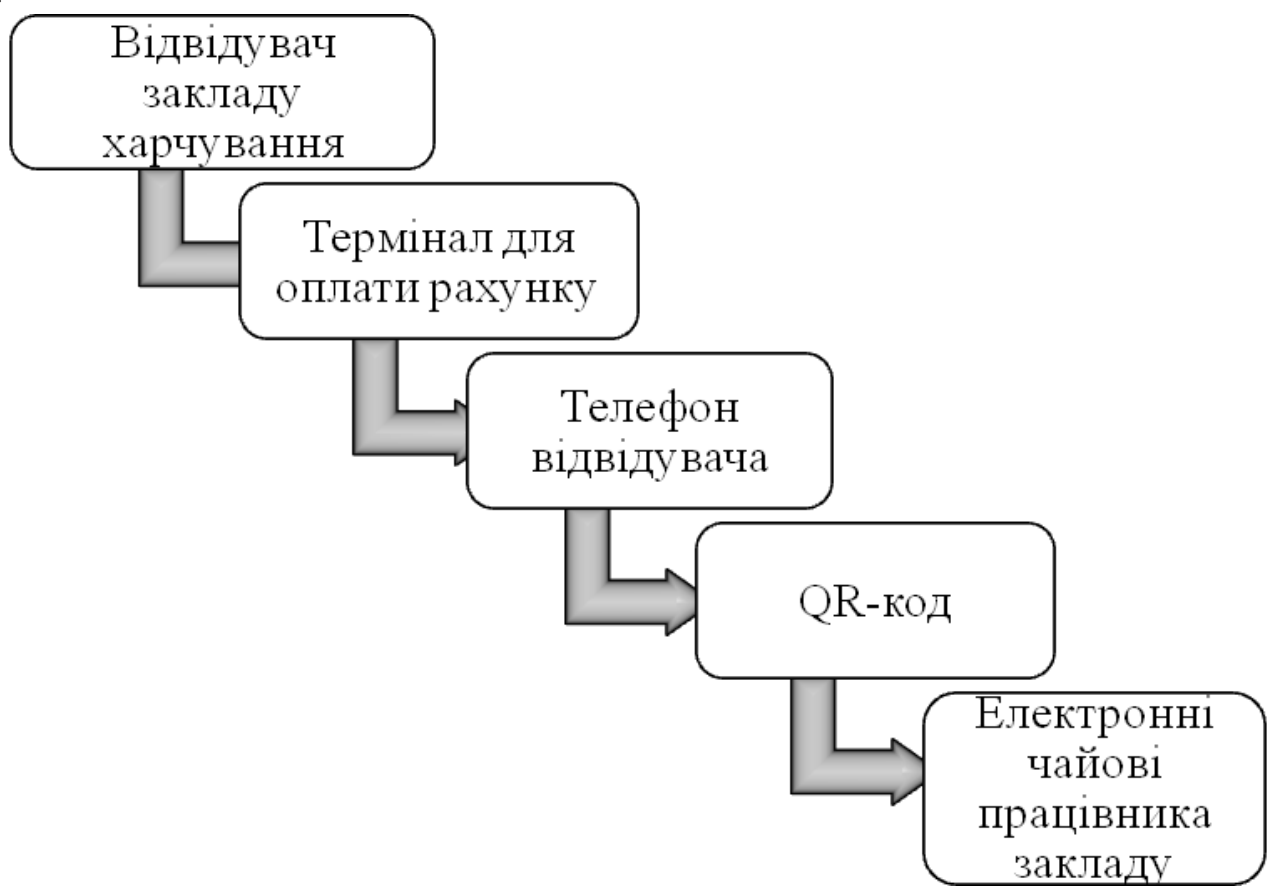

Puc. 2. Процес отримання електронних чайових (розробка автора)

Fig. 2. The process of obtaining electronic tips (author's development) 
Відвідувач закладу прикладає свій телефон до терміналу, потім наводить камеру на QR-код і оплачує послугу харчування та може залишити електронні чайові.

Важливо, що відвідувач, залишаючи електронні чайові, потрапляє через програму безпосередньо на особисту сторінку офіціанта, а не просто кидає їх у нікуди. Гроші мають конкретного одержувача. При чому гостю на вибір пропонується або фіксована сума чайових - 10-15-20\% - або він сам може написати суму, яку вважає за потрібну.

Інший спосіб електронних чайових полягає в наступному: офіціант вибирає в терміналі спосіб оплати з чайовими, вибирає себе, підтверджує, вбиває суму чека і за умовчанням пропонує гостю залишити $10 \%$ чайових - на розсуд гостя, як і завжди. Зверху на дисплеї $є$ примітка, що максимальний ліміт становить $30 \%$. У межах цих відсотків гість може залишити чайові. Сума чайових на цьому етапі не вказується, вона з'являється лише у відсотках. Далі офіціант натискає зелену кнопку, висвічується фінальна сума і гість ресторану прикладає карту до терміналу.

Сьогодні такі нововведення в закладах харчування працюють вже досить активно. Це пов'язано ще й з тим, що кількість готівки на руках у гостей стає дедалі меншою, транзакцій за банківськими картками становить близько 85-90\%. Однак бажання гостей віддячити співробітникам нікуди не поділося. Вони, як і раніше, хочуть залишити чайові і при цьому не зв'язуватися 3 дрібними грошима, розмінами. Така система $\epsilon$ досить зручною, як для відвідувачів закладу, так і самого персоналу.

Висновки. У науковій статті визначено та охарактеризовано основні проблеми 3 якими стикнулася сфера обслуговування в період пандемії.

Ресторанний бізнес проходить складний період - час пандемії. Зазвичай у ресторанах та кафе прийнято залишати чайові. Залишати чайові - ознака гарного тону, адже так відвідувач дякує офіціанту за хороше обслуговування.

У Свропі вже вважається стандартом вказувати код на чеку для швидкої та зручної оплати рахунку. В Україні також починають використовувати на практиці інтеграцію автоматизованих систем для ресторанного бізнесу з QR-програмами. Гості таких закладів можуть покликати офіціанта, попросити рахунок або сплатити замовлення через смартфон, не чекаючи здачі.

Всі ці нововведення не тільки оптимізують роботу ресторану, а й знаходять позитивний відгук у відвідувачів.

Слід зазначити, що ця послуга потрібна не лише з боку закладів та офіціантів, а й з боку гостей. Досить часто виникають ситуації, коли після обіду чи вечері в ресторані гість хоче залишити чайові, але не має з собою готівки.

Щоб користуватися цим сервісом, офіціант реєструє свою особисту карту в POSтерміналі, через чіп-рідер з неї запам'ятовується прізвище, ім'я та номер. Тут немає електронних рахунків, електронних гаманців, а гроші безпосередньо приходять на банківський рахунок офіціанта. Отже, система захисту така ж надійна, як і у банківських карток.

Сьогодні чітко прослідковується зацікавленість відвідувачів закладів харчування до безпечних, автоматизованих програм, які впроваджуються в сфері обслуговування.

1. Архіпов В.В., Іванникова Т.В., Архіпова В.А. Ресторанна справа асортимент, технологія i управління якістю продукції в сучасному ресторані. 2-ге видання: Навч. посіб. К.: Центр учбової літератури. Фірма «Інкос», 2008. 384 с.

2. Мальська М.П., Пандяк І.Г. Готельний бізнес теорія та практика. Підручник. 2-ге вид. перероб. та доп. К.: Центр учбової літератури, 2012. 472 с.

3. Самодай В.П., Кравченко А.І. Організація ресторанної справи. Навчальний посібник. Суми: Видво СумДПУ, 2015. 424 с.

4. Информационно-образовательная площадка для рестораторов: Чаевые в ресторане. «Общий котел» или каждый сам за себя? URL: https://place.lemma.ru/article/chayevyye-v-restorane-obshchiykotel-ili-kazhdyy-sam-za-sebya (дата звернення: 29.10.2021). 
5. Коронавирус: как украинские рестораторы ведут бизнес в условиях пандемии. URL: https:// www.restorator.ua/post/coronavirus-how-ukrainianrestaurateurs-do-business-in-a-pandemic (дата звернення: 30.10.2021).

6. Ресторанний бізнес в умовах пандемії коронавірусу: проблеми та напрями трансформації моделей розвитку. URL: http://market-infr.od.ua/journals/2020/42_2020_ukr/22.pdf (дата звернення: 29.10.2021).

7. Publish Україна. Все, що треба знати про чайові. URL: https://publish.com.ua/biznes/vse-shcho-trebaznati-pro-chajovi.html (дата звернення: 30.10.2021).

8. Restik. Технологические тренды в ресторанном бизнесе 2019. URL: https://restik.com/blog/tekhnologicheskie-trendy-v-restorannom-biznese-2019/ (дата звернення: 30.10.2021).

\section{References}

1. Arkhipov, B.B., Ivannikova, T.V., and V.A. Arkhipova. Restaurant business range, technology and product quality management in a modern restaurant. Kyiv, Center for Educational Literature. Firm "Inkos", 2008.

2. Malska, M.P., and I.G. Pandyak. Hotel business theory and practice. Kyiv: Center for Educational Literature, 2012.

3. Samodai ,V.P., and A.I. Kravchenko. Organization of restaurant business. Sumy, Publishing House of Sumy State Pedagogical University, 2015.

4. "Information and educational platform for restaurateurs: Tipping in the restaurant. "Common boiler" or each for himself?” Place.lemma. place.lemma.ru/article/chayevyye-v-restorane-obshchiy-kotel-ilikazhdyy-sam-za-sebya. Accessed 29 Oct.2021.

5. "Coronavirus: how Ukrainian restaurateurs do business in a pandemic." Restorator, www.restorator.ua/post/coronavirus-how-ukrainianrestaurateurs-do-business-in-a-pandemic. Accessed 29 Oct.2021.

6. "Restaurant business in the context of the coronavirus pandemic: problems and directions of transformation of development models.” Infrastruktura rynku, marketinfr.od.ua/journals/2020/42_2020_ukr/22.pdf. Accessed 29 Oct.2021.

7. "Everything you need to know about tips.” Publish Ukraine., publish.com.ua/biznes/vse-shcho-trebaznati-pro-chajovi.html. Accessed 30 Oct.2021.

8. “Technological trends in the restaurant business 2019.” Restik, restik.com/blog/tekhnologicheskie-trendyv-restorannom-biznese-2019. Accessed 30 Oct.2021.

УДК 001.895:[004.738.5:339.138]:338.488

doi: 10.15330/apred.2.17.211-226

Барвінок Н. В.

\section{РОЛЬ ІННОВАЦІЙНИХ ІНСТРУМЕНТІВ ІНТЕРНЕТ-МАРКЕТИНГУ У} ПРОСУВАННІ ТУРИСТИЧНОГО ПРОДУКТУ

Уманський державний педагогічний університет імені Павла Тичини,

кафедра технологій та організації туризму i готельно-ресторанної справи,

вул. Садова, 2 ,Умань, Черкаська обл.,

20300, Україна,

тел.: +380671071971,

e-meil: barvinok.n@udpu.edu.ua,

ORCID:0000-0002-6661-4780

Анотація. У статті розглядаються питання значення впровадження інноваційного підходу маркетингу до просування туристичного продукту на ринку туристичних послуг в умовах глобалізації та інформатизації сучасної економіки й суспільства в цілому. Ринок 